\title{
A Scientific Study on the Holy Spiritual Descending in NRMs of Korea: Focus upon the Paranormal Phenomena of the Holy Spirit by the Victor
}

\author{
Han Gang-Hyen \\ The Society for the Scientific Study on the Holy Spirit (SSSH), Bucheon, South Korea
}

\begin{abstract}
The limit and the problem of modern religion and science are due to the materialistic, mechanistic, and dichotomous thought that separates humanity from God, spirit from body and I from you. Indicating that the methodology is wrong, the author will suggest an alternative to solve its problem. In the body, the author will introduce the paranormal phenomena focusing on the descending of the Holy Spirit by the Victor on NRMs in Korea. The author will speak of the differences between Aura and the light of the Holy Spirit using some new methodologies of participant observation by film photo-graphing and interviewing testimonies from fieldwork. Furthermore the author attempted to research scientifically how the light of life emitted from the Victor influences humanity and all things. The author will tell the theory of bio scientific and biblical salvation and immortality based on somatic. This paper will contribute in revealing the invisible God and the Holy Spirit to be physically seen.
\end{abstract}

Keywords: The Holy Spirit, participant observation, The Victor, immortality, the Descending of Holy Spirit, Paranormal Phenomena, Dichotomous thought

\section{Introduction}

So far, around 100,000 religions have risen and fallen; however, nobody has realized the will of God and the truth of the Bible. Nobody practiced them because they did not know the controlling spirit of humanity is wrong. Therefore, humanity has become the slave of Satan that is tempted by desire. As all humanity came from one ancestor, they are brothers. However, they insisted about the religion of exclusiveness stressed the absolute, letting a blind dogma lead people, and causing wars because they are crazy, do not get out of dark spiritual prison, entropy.

It means that as today's theology which was made by ignorant people's illusion is not theology (神學) but human's thoughts. Also the theology is not faith but man-made-faith (人仰), not religion by God, but the work of Satan, that grasps for authority and kills life. That is, there was no work by the Holy Spirit so far.

Because there was no religious work by the Holy Spirit, people did not know about the Holy Spirit, they believed slogans like "God wants", killed countless children of God, in "Holy wars" such as the Crusades, which is insulting to God. According to the scriptures, killing people is a sin and you will go to hell. Although they committed a sin of killing people, can they go heaven?

Han Gang-Hyen, General Director of SSSH, The Society for the Scientific Study on the Holy Spirit (SSSH). 
The religious work of denying the sound of conscience and the word of the Holy Spirit hints that the era of religion is finished. Now Kurzweil's work "Critical Point" or "Turning Point" tries to determine if humanity has a bright and hopeful future or if a miserable collapse of humanity's is near.

Kurzweil, an American scholar, informs beforehand the turning point of such a new civilization and the vision of a new future from the situation of a scientist through "The Singularity is Near." Additionally, Thomas Magnell, a professor, said that in a new era, we need intelligence to think of human existence's meaning and value and the importance of ethics, and there will change in values in his thesis "The Associate of Value Inquiry".

As the writer of this paper who is a researcher of the world scriptures, and prediction, futurologist, and Human cultural research scholar.

I think now the time of the Homo sapiens, Super-sapiens, Trans-human is passing and "The Turning Point", when humans become a New-human and enjoy eternal life and happiness is approaching. In other words, now is the time when everybody no longer has a desire for the evil spirit that causes jealousy and selfishness and makes people fight each other, they should be reborn as the Holy Spirit. I established with two other Korean NRMs researcher Mr. Lee Gyong-Woo, and Ms. Kim Young-Suk IANC (International Academy of Neo-humans ${ }^{4}$ Culture) that studies neo-humans' culture in "Neo-human Age". I named that it is the IANC (International Academy of Neo-humans Culture). ${ }^{5}$

Also, according to the world scriptures and prophetic books, especially Korean Gyeokamyourok with 100 percent accuracy, before "Turning Point" and "Neo-human Age", the Victor Savior will come to the world. I came to know the advent of the Victor Savior in detail through researching the prediction about the Victor Savior. Mr. Cho Hee Sung, the last angel in the Revelation of the Bible revealed that the Victor Savior, the Maitreya Buddha, and Jeongdoryeong will appear as one person with the Holy Dew Spirit in Korea. That is the hidden secret in all the scriptures. The righteous men, the white group in "Victory Altar (SuengRi-JeDan)" that leads Korean religious movement explain that due to the advent of the Victor Savior, the long-cherished problem of humanity was supposed to be realized. I think that the insistence of the Victory Altar (SuengRi-JeDan)'s righteous men and the sermons' words of the Victor are very persuasive. Furthermore when the believers of Confucianism, Buddhism, the Taoism, and Korean new religions gather and attend a worship service together; it was an unprecedented event. It made the writer of this paper surprised.

I will explain the reason why the existing pastors and Kim Yeong Sam, an elder president of Christianity, persecuted the Victor Savior and the Victory Altar in the next chapter. If you listen to this thesis carefully, you will see it will be good news because the science of the Victor's immortality is very biblical and scientific; it can be a religious revolution.

\section{The Body}

If the Victor Savior appears to the world and the light of the Holy Dew Spirit's bright wisdom comes to people, the incomplete teachings that are very ignorant and kill the life of God and even the scriptures will

\footnotetext{
${ }^{1}$ See Ray Kuzweil, The Singularity Is Near (New York: Viking Penguin, 2006), ch.6.

2 See Thomas Magnell, "Critical Points for Civilization, Intelligence, and Value," Journal of Value Inquiry, vol. 38, no. $2,2004$.

3 "Turning Point": It means the critical point of changing as a new movement cultural, philosophical, and religious situation.

${ }^{4}$ Han Gang-Hyen, The Final Issue of NRNs in the World, Geum-Seong Publishing Company, Seoul, 2013. Retrieved from https://www.amazon.com.

5 Refer to Journal Vol 3. Oct 2015, the purpose of establishing of IANC pp. 1-2.
} 
perish according to the Bible. The prediction about the fruit of life meaning the Holy Dew Spirit, and the advent of the Victor have been hidden as the top secret of God in the world, which evil spirits rule. They have been sealed and predicted metaphysically not to be known to greedy people, the Victor in the Victory Altar ${ }^{6}$ who appeared in the late period of 20th century has revealed the secrets of heaven hidden in the East and the West. The work of the Holy Spirit is accomplishing the will of heaven. It started 150 years ago and has been revealed earnestly to the world with the Korean new religious movement.

Unlike the world new religious movement, there are four unique characteristics in NRMs of Korea:

(1) The GaeByeok Thougt(Opening to Re-Create Post-heaven).

(2) The Thought of Maitreya and Messiah.

(3) The Thought of unifying all religion into one.

(4) The Theory of building the New Paradise, the Idea world.

Their ultimatums are building the paradise and an immortal world, which are the common subjects of all the new Korean new religious movements. Therefore, the final hidden issues are to find out and distinguish the Victor, Messiah, Maitreya Buddha and Jeongdoryeong that is suitable to $5 \mathrm{WH}$ based on the condition of the hero's symbol in the Bible, the Buddhist scriptures, and prophetic books and to reveal the essence of "the hidden manna", "the Holy Dew Spirit", "the fruit of life", "the Sweet Dew", "Amrta, Ambrosia", "the Sweet Dew Water", and “The Elixir of Life”. 『Gyeokamyourok』 ${ }^{8}$, Namsago (南師古)'s prophetic book, an Eastern Nostradamus, predicted 4 angels in Yin and yang and Five-Elements school (陰陽五行).

\section{The 4 Angels Led the Korean New Religious Movements}

1. Angel Soowoon, Mr. Choi Je-Woo (水雲崔濟愚) has religious groups such as “Cheodo religion", "Soowoon religion" and opened the door of the north. Further he created “東學”, a new learning in order to reform the corruption and contradiction of Confucianism and predicted that nonpolar great Tao (無極大道) would be opened, an fairy medicine (仙藥) that makes people fairies, would appear, and the world of eternal youth and immortality would come. There are 「Donggyeongdaedaejeon $\rfloor,\lceil$ Yongdamyoosa $\rfloor$ as the major scriptures.

2. Angel Hwawoon, Mr. Gang Il-soon ( '火雲' , 姜一巡) has dozens of separate religious groups such as "Jeungsan religion", "Daesoon Jinleehoi", which opened the door of the south, and proclaimed the Big Open of posterior pointing out the degeneration of Buddhism. Also he predicted that a lot of ascetics would appear in Korea and that we should prepare for it. He anticipated the advent of the paradise and the Maitreya Buddha with the Sweet Dew. Furthermore he foretold that the Maitreya Buddha would bring the rain of Dharma.

There are the major scriptures such as 「Junghwagyeong (中和經)」, 「Daesoonjeongyeong (大巡典經)」

\footnotetext{
${ }^{6}$ The Victory Altar (勝利祭壇): The name of the Victory Altar came from the order of the Fifth Angel (Park Tae Seun) in a prophecy according to the Bible as one of Korean new new religi-ous movement, The original whole name is "The eternal religion God's Holy Society Victory Altar (勝利祭壇). Some journalists and broadcasters who did not understand the concept of immortality of the Victory Altar" call the name to belittle and allude the Victory Altar. However, examining the name, it is originated from the Altar where God who preaches immortality stays. The Victory Altar hopes that people call it the Victory Altar for shorter, also I will use the name in my thesis.

7 Ibid, Han Gang-Hyen, 『The Final Issue of NRNs in the World』 pp. 49-55.

8 『Gyeokamyourok』: 『Gyeokamyourok (格菴遺錄)』: which Nation's Central Library has, the number of the list of old books, Old No: 1496-4. It is a well known Korean prophetic book written by Namsago (南師古) 450 years ago. It is a representative of Korean prophetic books. His nickname is Gyeokam. He was born in Gyeongsang province in 1509. He was an expert in astronomy.
} 
3. Angel Mokwoon, Mr. Pak Tae-seon ( ‘木運” , 朴泰善) built the Faith Village (信仰村) in Bucheon city Sosa area from the mid-1950s and established Jeondogwan on the base of new Christianity's foundation. Furthermore, he caused a psychic revival pouring the incomplete Holy Dew Spirit, with healing powers using his hands. He is known as "The Lion of the Fire" in the East. He testified about Jesus and led over 1.5 million followers. However, after the advent of the Victor, the Gold luck angel, he changed the name of Jeondogwan (傳導館) into Cheonboogyo. He criticized the corruption of Christianity and said about Christianity's wrong faith. Furthermore as he started to criticize that Jesus is fake, many followers returned to existing churches. He predicted the advent of the final Victor through "his Sermon and the Faith newspaper". In addition, he predicted that one is saved by going to the man who pours the Holy Dew Spirit, listening to the Victor, being reborn as a new man with a new mind, and being accomplished as Gods, through the tapes of sermons and $\lceil$ the Faith newspaper」.

4. Angel Gumwoon, Mr. Cho Hee-Sung ('金運”, 曺熙星) ${ }^{9}$ became a Victor on October 15th, 1980. He then established the Victory Altar and preached the science of immortality scientifically and medically based on the principle of blood. Also he was a sincere elder of the Presbyterian Church. He was led to Jeondogwan by the Holy Spirit, and was chosen by God as the captain of the Big Opening to complete the work of the Holy Spirit. He was led to the Secret Chamber and received severe trials and overcame the spirit of death, in the Armageddon's war, fighting against himself, and became a Victorious God. After becoming a Victorious God, he solved the 66 volumes of the Bible, in an hour. He also tried to foster a lot of righteous men through preaching the theory of new salvation and the theory of the Savior. The Victor, Mr. Cho Hee Sung, said only if one looks at the Victor who pours the Holy Dew Spirit, practice the new words of the Victor, they will become righteous men, and become God, will be saved. He says the secret of immortality in the Victory Altar every day and pours the Holy Dew Spirit.

I will now introduce the paranormal phenomena focusing on the descent of the Holy Spirit by the Victor Cho Hee-Seong at SeongRi-JeDan (Victory Altar).

\section{Paranormal Phenomena of the Holy Spirit Advent}

\section{The Hidden Manna of New Heaven and Holy Spirit}

First, look at these four pictures.

\footnotetext{
${ }^{9}$ For the Victor Cho Hee-Sung: There were a lot of persecutions from the government, broadcastings and newspapers, and mass-media by announcing distorted information. I think all new religions were treated like that at the beginning. Also, I will reveal that the mass-media distorted in reporting about the Victory Altar missing the Reincarnate Maitreya Buddha's working with His other selves, His amazing accomplishments of Five Covenants, mysterious spiritual experiences, and falling the Sweet Dew that are immortal spirit.
} 


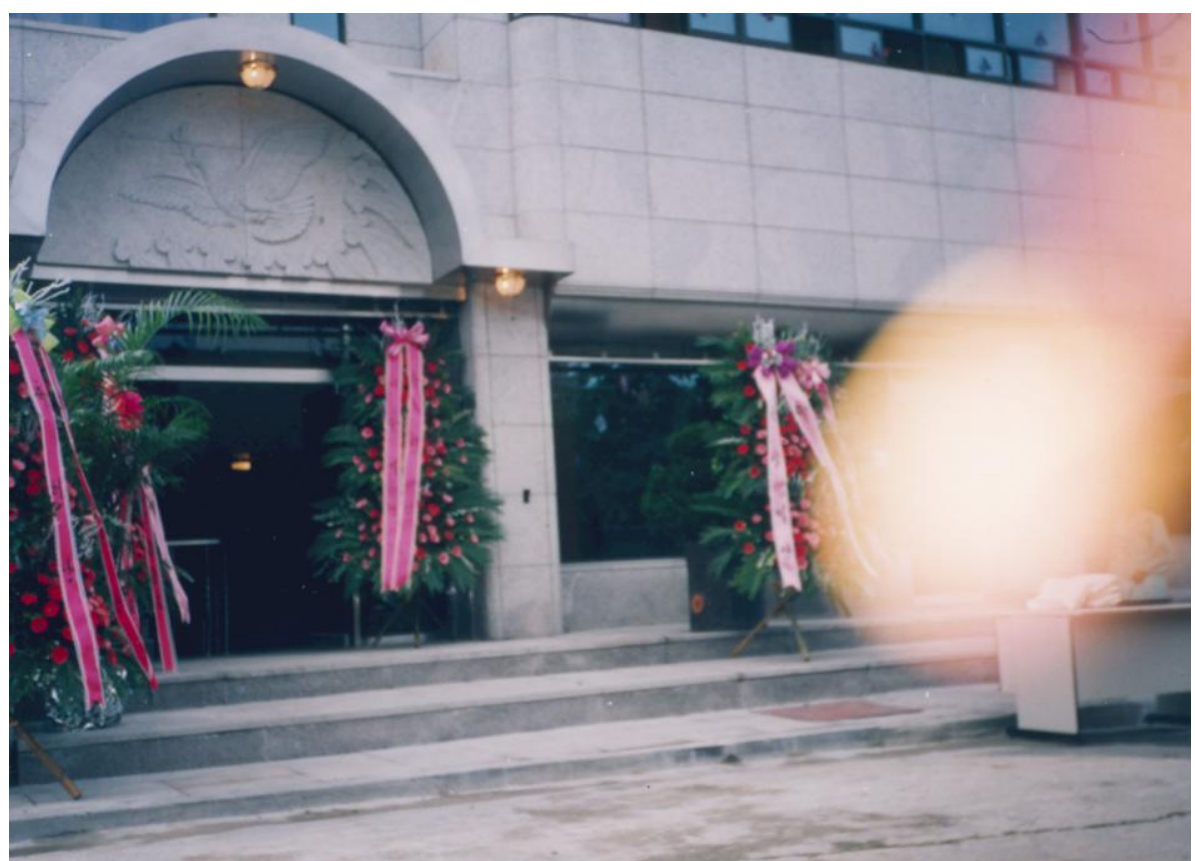

Figure 1. The Holy Dew Spirit is the immorta1 spirit of the victor, this occurred during the opening ceremony of the Victory Altar on August 12th, 1991 in front of the Victory Altar.

When the Victor Savior comes to the world, the manna of heaven like dew will fall according to the Bible, the Buddhist scriptures, Tao Te Ching (道德經), and 「Gyeokamyourok」. This dew is different from the dew that Moses poured in the desert in the Bible.

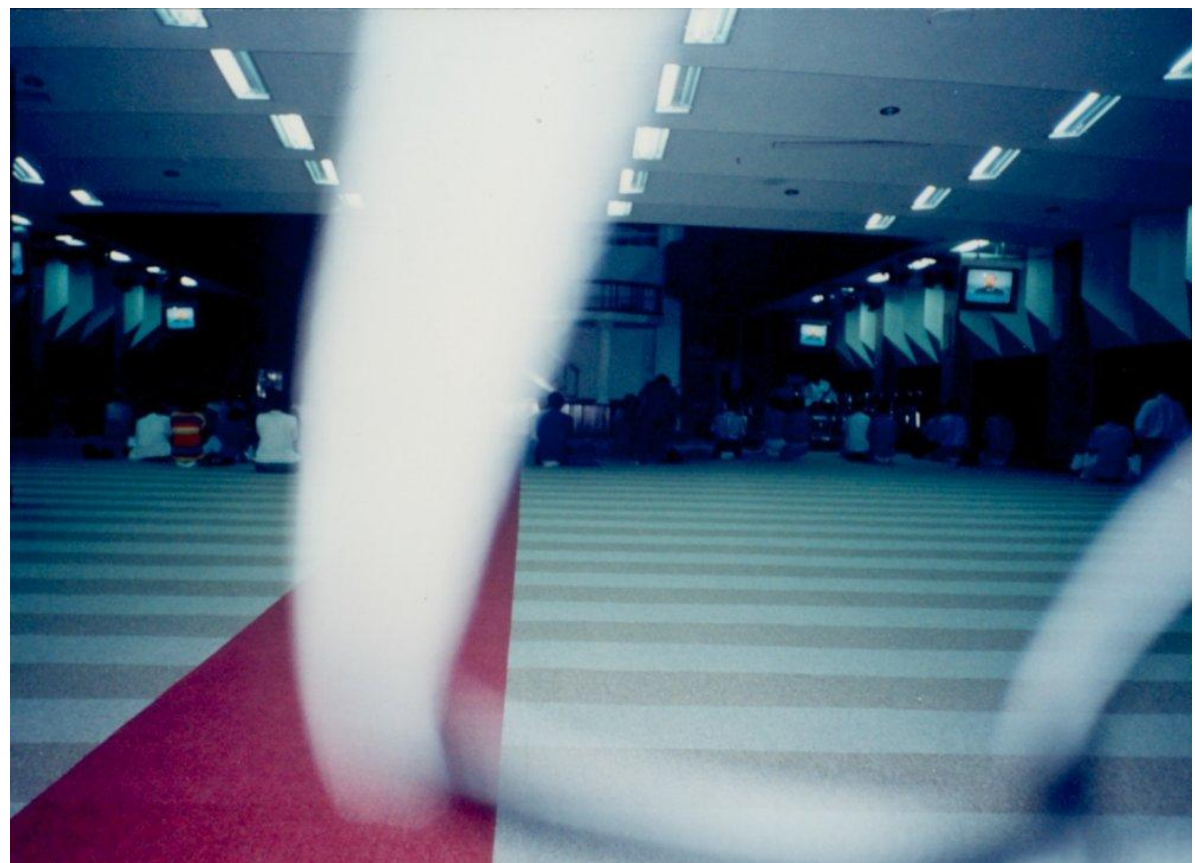

Figure 2. It was taken in the early period of 2000 when the Victor was sent to prison, this is not only the symbol of New Heaven but also the other selves of the Victor, which can pass through the concrete floor freely. 


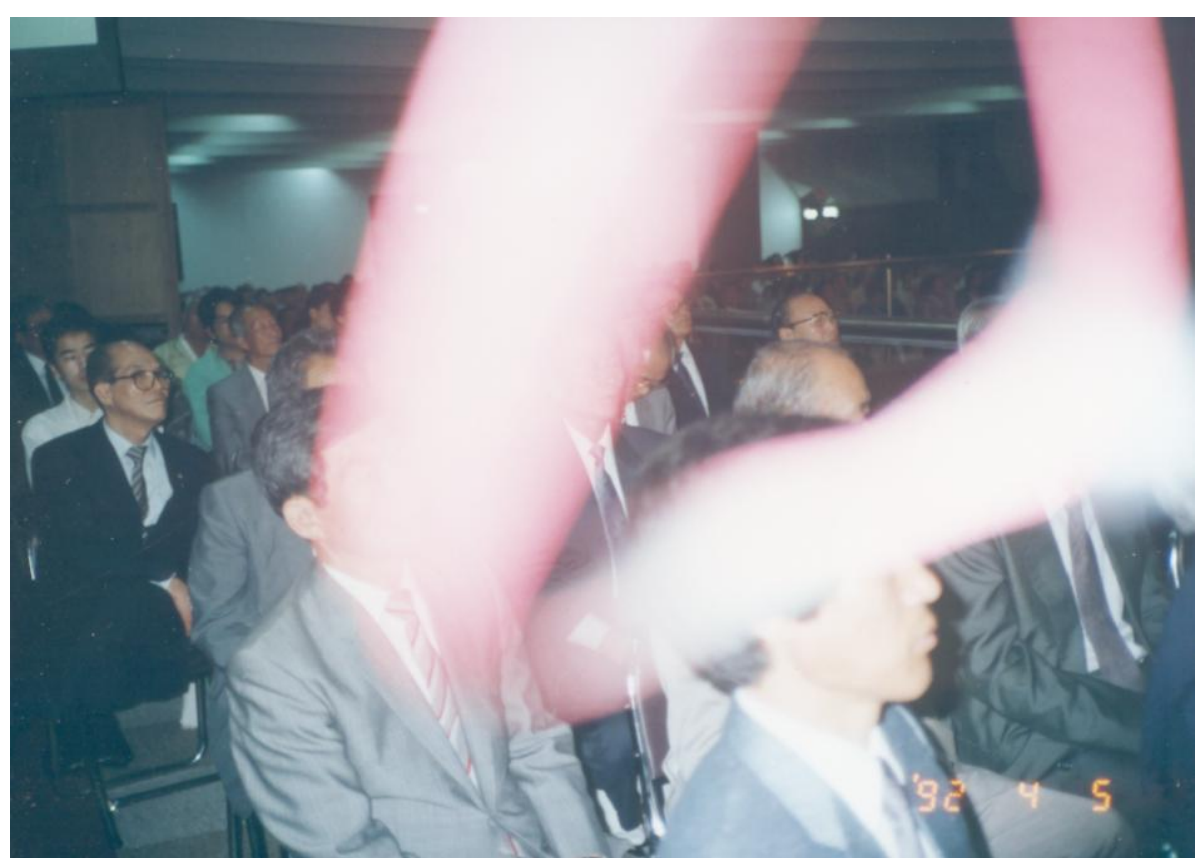

Figure 3. This photo was taken on April 5th, 1992. This is the manna of heaven, if it permeates people, it kills the spirit of death in them and people reach nirvana. Therefore, people can live forever if they receive this manna of heaven.

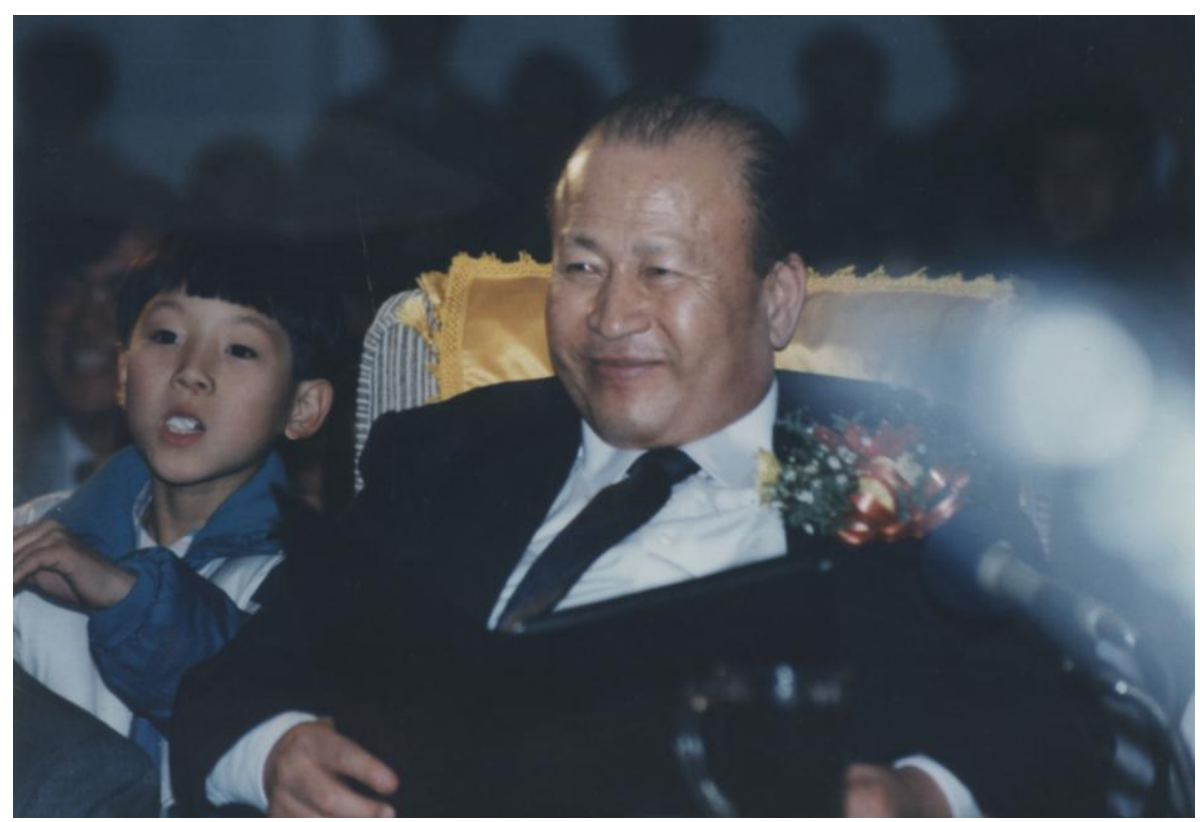

Figure 4. This is a photo of the Victor emitting the Holy Dew Spirit to the followers of the Victory Altar at an event of the Victory Altar. The Holy Dew Spirit comes out from the whole body of the Victor. It is evidence that God accompanies him. When the Holy Dew Spirit appears, people can smell the fragrance of lilies.

\section{The Meaning of the Holy Spirit \& the Hidden Manna}

According to Hosea 14:5-6 in the Bible, when the Victorious Savior comes, God will become the dew and fall. Therefore, when the Holy Dew Spirit falls, it is evidence that the Savior to save all dying humanity came. The Buddhist scriptures record that the man who brings the Sweet Dew water is the Maitreya Buddha.

$\lceil$ Gyeokamyourok」, a Korean prophetic book with 100 percent accuracy predicted when Jeongdoryeong 
appears to the world, he will have the Sweet Dew. The Holy Dew Spirit and the Sweet Dew indicate the same thing. ${ }^{10}$

What is $\ulcorner$ Gyeokamyourok (格庵遺錄)」?

$\ulcorner$ Gyeokamyourok (格菴遺錄)」 is a Korean prophetic book. It is a representative of Korean prophetic books. It was written by Namsago 450 years ago. His nickname is Gyeokam. He was born in Gyeongsang province in 1509. He was an expert in astronomy. When he was young, he met one transcendent person and received the predictions about the future of Korea and the world from him. He recorded the prophecies in this book. The book was registered in the National Central Library.

After receiving the revelation of heaven around 500 years ago, Nam Sa-Go (南師古) wrote this prophetic book, which is famous for a book of God (神書). It has a master key to solve the secrets of New Heaven existing in prophetic books in the world. Therefore, its predictions about the Victor Jeongdoryeong and the era of neo-humans. It is so persuasive that Korean new religious groups and spiritual leaders often cite the book to establish their authority. 「Gyeokamyourok」 records that the Sweet Dew Water (甘露水 = soma 酒 of New Heaven) is the light of Dharma that the Maitreya Buddha emits, that is spiritual manna that neo-humans eat.

To be admitted as the Victor Savior of the Bible, the hidden manna of new heaven is necessary to meet the condition of the Victor Savior. I will examine the manna in the Bible.

\section{What Is the Hidden Manna of the New Testament?}

The dew in the Old Testament and the New Testament is different. The manna in the old Testament is a physical manna, the sealed hidden manna in the New Testament is the spiritual (靈) manna that makes people immortal for a new era.

The Bible surely records, "Your forefathers ate the manna in the desert, yet they died. But here is the bread that comes down from heaven, which a man may eat and not die, according to John 6:49". However nobody knows the essence of the hidden manna except the Savior. Also John 6:27 writes, "Do not work for food that spoils, but for food that endures to eternal life", Ignorant sinners that have no idea about the immortal hidden manna fit that prophetic passage to the pseudo savior, but people are not deceived by the fabrication.

The Lord of God said, "You will eat meat fully in the evening, and eat rice cake in the morning". In that evening, quails covered the camp place and the next morning, dew fell down densely on the ground, the dew disappeared and something white and round like frost piled there. The Bedouins people of Israel call the manna (mana as soma juice) of the Bible the food from heaven. I think "mana as soma", is originated from mannu of the old Egyptian meaning food or mann of the Arabic which has the same meaning as food. That is, it can be defined as something coming from heaven, it can be symbolically defined as the food of heaven or food that Gods eat, which came from its origin and meaning.

Almost of Christians think Jesus as the Messiah. However according to my research, he never corresponds with the Bible, it is non-biblical. Like the prophecy of Moses who saved the people of Israel from slavery, the second Savior, true Messiah, should do the same as Moses did. The man who saves dying people with the Hidden Manna, is the true Savior and Messiah according to the followers of the Victory Altar. I think that their insistence is more persuasive than the baseless Jesus' second coming' of Christians.

10 The Manna of New heaven: THE BIBLE, 「JPS HEBREW ENGLISH TANAKH」, (Philadelphia, THE JEWISH PUBLICATION SOCIETY, 1999), p. 148: Exodus 16: 13, Numbers 6-9 of the Bible. 


\section{The Meaning and Origin of the Hidden Manna Recorded in the Bible}

\section{What Is the Manna?}

First, let me check the origin and the essence of the hidden manna of the Bible and the prophetic recordings analyze its meaning. Manna is miracle food from heaven, according to Exodus 16:14-31, Numbers 11:6-9, Deuteronomy (8:3), Nehemiah 9:20-21 Psalm (78:23-24), John (6:31), Revelation (2:17) in the Bible. When Moses took the Israel people to the desert from Egypt, there was no food with them. So they almost starved to death. They complained to Moses. So he prayed to God to save them.

\section{The Comparative Study Between Mosses' Manna and the Hidden Manna}

According to not only the predictions of the world scriptures but also the insistence of the followers of the Victory Altar, the hidden manna is the most important aspect to accomplish eternal life and it is the possess condition of the Victor. I think that is the master key to solve the salvation of humanity. Each scripture predicted that the man who carries the hidden manna is the Victor Savior, the true Messiah. The Buddhist scriptures foretold that the Maitreya Buddha would appear, His symbol would be the Sweet Dew. According to

$\lceil$ Gyeokamyourok」, a Korean prophetic book with 100 percent accuracy, records that Jeongdoryeong (the Savior that Koreans wait for) is the son of heaven, His symbol is the Sweet Dew. Like this, the Sweet Dew is the life food of common heaven in the scriptures. Then why did God predict hiding the secret of new heaven? There are a few people who know the reason. 「Gyeokamyourok」 records in detail why God hid the bad situation of God and the essence of the hidden manna.

\section{The Sweet Dew Predicted in「Gyeokamyourok 」}

First, I will examine, Eunbiga (隱秘歌), the first part of 「Gyeokamyourok」, the Korean prophecy, says that the man who pours out the Sweet Dew is the Savior.

Also, Haeinga (海印歌) of 「Gyeokamyourok」 says that the Sweet Dew is the essence of the elixir which previous saints waited for and dreamed about. Doboosinin part of 「Gyeokamyourok $\rfloor$ talks about the power of the Sweet Dew as follows: the mysterious Sweet Dew makes old men to change into a teenager's strong body, they are never old, and they stay as young men forever by the following the Eunbiga (隱秘歌)

“白髮老軀無用者가 仙風道骨更小年에 不老不衰永春으로 不可思議海印”

The Holy Dew Spirit that is not seen to the naked eye, falls in the Victory Altar is an immortal manna, and the light of nirvana that cures spiritually or physical injured life. It is the light of life that can permeate any material without being interrupted.

The hidden manna that comes from the Victor, the golden-lucky 7 angel is a mystical paranormal phenomenon. This is to make a unique phenomenon come together service for the Victor because he is pouring down the Hidden Manna every day without another religion.

In the history of humanity, are there men who teach the way of immortality pouring the Holy Dew Spirit, the spirit of God, do the work of salvation as the true Messiah? There are not except the Victor in the Victory Altar. The reason that people cannot refuse the insistence of the Victory Altar is because the Holy Dew Spirit still falls and the Victor Savior shows His power through 5 covenants. There is no Victor, Maitreya Buddha, and Jeongdoryeong that correspond to the predictions of the scriptures like the Victory Altar. Still more, there is no place to tell immortality in a physical body. All teachings are incomplete, and there were no doctrines or philosophies that save all humanity. If there was a true Savior, he would have revealed the hidden manna and the words of physical immortality. 


\section{The Prediction About the Messiah in the Bible and the Hidden Manna}

Below are the key passages about the Holy Dew Spirit in the Bible.

(1) Hoseah 14:5 writes, "I will be like the dew to Israel; he will blossom like a lily". It means that the Victor meaning Israel emits the dew and the dew itself is God. That is, the Victor is God.

(2)Isaiah 26:19 records, "As the sparkling dew refreshes the earth, so the Lord will revive those who have long been dead". God predicted in the Bible if the Holy Dew Spirit falls down, death will disappear on the earth.

(3) Joel 2:28-30 "Afterwards, I will pour out my spirit on everyone: there will be bloodshed, fire, and clouds of smoke". The terms of bloodshed, fire, and clouds of smoke correspond with fire $=$ 火, rain $=$ 雨, Dew $=$ 露, three abundant God's Spirit (三豊海印) in『Gyeokamyourok』. I find that the eastern and western prophecy about the Sweet Dew coincides.

(4) Micah 5:7, "The people of Israel who survive will be like refreshing Dew sent by the Lord". The Lord says that He will send Dew to people, which means that He will attend to people as Dew.

(5) Psalms 133:3, "It is like the dew on mountain Hermon, falling on the hills of Zion. That is where the Lord has promised his blessing, life that never ends". This explains means if the Holy Dew Spirit falls, death disappears and immortality is accomplished. Like this, the hidden manna that falls in the Victory Altar is the Sweet Dew, it is an immortal food (靈物) of heaven, the insistence of the Victory Altar that people can live forever with physical body is supported by the scriptures, prophetic books and archeological material.

(1) The Victor Savior Emits the Immortal Manna.

Hoseah 14:5 writes, "I will be like the dew to Israel; he will blossom like a lily". In these words, I is God because the words of the Bible is about God. Also, I could find a core ring that explains the hidden manna and the Victor in Revelation 2:17, "To him who overcomes, I will give some of the hidden manna. The prediction is the most important key that determines who the Victor is".

(2) Futurology and the Truth of Prophecy.

Futurology is the study of the future of human beings; it is needed to understand the meaning and feature of future well. The future has a relationship with the life of the present. It has the dual meanings of not only the tomorrow of today but also the today of tomorrow. It is like identical twins, and the connection of time. That is: the future is influenced by the present; it is the production of humanity's present behaviors. So the future is the mirror of the present. Today is the portrait of the past; the present face and the body condition are "the portrait of the mind", the results of one's past values, thoughts and behaviors.

Therefore, the basic aim of futurology is to announce the whole change trend, to anticipate the desirable condition of the future, and to suggest the direction of selection. It also helps ultimately in optimal decisions-making and choosing alternatives, and suggests feasible concrete things. In modern society, futurology becomes an essential method to the managers of companies or in decision making departments. Studying the future is not foretelling but forecasting. Also prophecy is different from forecasting in its methodology. It can anticipate and foretell through the spiritual inspiration of light transcending time and space.

There are many futurologists including Ray Kurzweil who forecast and insist that the dream society of the 21 st century will be created by in the aspect of scientific technology. Ray Kurzweil uses a terms, "Singularity" to express the moment scientific technology transcends humanity. The writer of this paper wants to say that "Singularity" comes in all areas of learning, both in religion and science. The Critical Points, that is the limit of 
science that humanity can neither be happy and nor live forever with the scientific technology, already came. Therefore, the wind of humanities' revival is blowing in Korea and other advanced countries. To know the future is important because we can prepare for it today. According to the prophetic books and the scriptures, the era of light will come soon. Next I will explain how the era of light will be built scientifically.

A lot of Korean new religions' leaders such as Moon Sun-myung (1920-2012) of the Unification Church, Ahn Sang-hong (1918-1985) of the WMS Church of God, Jung Myung-seok (1945-) of CJMS, Lee Man-hee (1931-) of the Shinchonji (New heaven \& Earth movement), Cho Yong-gi and so on call themselves "the Returned Jesus", "God of Father", "Mother in the Heaven", "True Parents", "Victor". But nobody has the possess conditions of the Savior and reveals the secrets of the Bible. There is only one person who pours down the hidden manna. That person is the Victor, Mr. Cho Hee-Seung (曺熙星) of the Victory Altar according to the followers of the Victory Altar

\section{"Mandala Dharma Flower Rain" in the Buddhist Scriptures}

Sakyamuni predicted "the Dharma of the Sweet Dew" in the Buddhist scriptures. Let's see how the Buddhist scriptures foretell about the Reincarnate Maitreya Buddha. The Buddhist Scriptures express the Sweet Dew (甘露水 = soma juice) as the light of great nirvana that the Reincarnated Maitreya Buddha pours out, the whole Buddhist scriptures such as the Great Nirvana Sutra, the Dharma Flower Sutra, and the Flower Adornment Sutra, say that the Sweet Dew is the symbol of the Reincarnated Maitreya Buddha.

The basic aim of Buddhist scriptures is reaching nirvana by receiving the Sweet Dew, according to Bomun part of the Lotus Sutra because the Sweet Dew removes humans' agony, birth, and death. The Buddhist Scriptures express the Sweet Dew (甘露) as the light of the great nirvana that the Reincarnated Maitreya Buddha pours out, the whole of Buddhist scriptures such as, the Great Nirvana Sutra, the Avatamska Sutra, and the Dharma Sutra say the Sweet Dew is the symbol of the Reincarnated Maitreya Buddha. According to volume 26 of the Avatamska, the Reincarnated Maitreya Buddha can fill the universe with His other selves, in an instance, pour down the Sweet Dew, and remove the agonies of people (分身編十方 甘露雨滅煩惱).

Mandala flower (曼陀羅華) and Flower Rain and 醍醐味 that symbolizes nirvana. According to Amita Sutra, in the land of happiness, the Reincarnate Maitreya Buddha always stays as His other self, the infinite Sweet Dew. Mandala flower rain that symbolizes nirvana always falls down there.

Therefore, I will introduce my enlightenment through the wisdom of the Sweet Dew using the term of Buddhism on the basis of the preaching of the Reincarnate Maitreya Buddha. Mandala flower rain is the Sweet Dew in the land of happiness, it has the light of wisdom without any obstacles. Also, it is the other selves of the Reincarnate Maitreya Buddha, and the Holy Dew Spirit. Those who lack good character are blind with sins and karma cannot see the Sweet Dew in the world of Mandala and cannot see things in advance according to

$\lceil$ Nirvana Sutra $\rfloor,\lceil$ Dharma Lotus Sutra $\rfloor$, and 「Flower Adornment Sutra . 「Pure Land Sambugyeong」 and 「Prajñā-Paramitā $\rfloor$ say that righteous men in the immortal land of happiness see the Reincarnate Maitreya Buddha in a naked eye. Therefore, it is necessary to pay attention to that mysterious immortal world where unprecedented people reach nirvana physically like 醍醐味 in Sosa Korea.

The Buddhist Scriptures record that 十住地 (the pure land that Mandala flower rain falls down and the Reincarnate Maitreya Buddha stays) is expressed as the Castle of the Sweet Dew, pure land, the door of the Sweet Dew, or Amita Palace. Buddha said before when people receive the light of wisdom from Amita Buddha, they can achieve immortal bodies and are physically in the stage of nirvana. What is the world of nirvana that 
醍醐味 symbolizes? What does nirvana have relationship with 醍醐味? What should people do to reach nirvana? There are four steps in explaining the process of reaching complete nirvana through cultivating themselves, comparing nirvana to the final refining of milk. According to Buddhism Sutra, there are four steps in the process of reaching nirvana.

A. The stage of achieving of Sudawon and Sadaham is small nirvana; its stage is like milk.

B. This stage is achieving of anaham, its stage is middle nirvana. In this stage, people's blood is like milk being refined through second process.

C. If people achieve fruit of 辟支佛 and 十住菩薩, their stage is called Great nirvana, their blood is like clear and pure a spiritual juice (生酬).

D. When people are on the stage of righteous men or Sakyamuni, their stage is called Great Nirvana. Their nature of Buddha and their blood is compared like the final refined steps of milk, 醍醐味. In fact, these terms compared to the steps of spiritual purification. The level of the Reincarnate Maitreya is this. He has an infinite life span, is the immortal existence (無量壽) that emits unlimited light (無量光), can change into a lump of fire anytime, also can change as His other selves like tiny dirt. Anyway, Nirvana Sutra compares the nature of people's Buddha to the process of refining milk. I could see the advent of the Reincarnate Maitreya Buddha was predicted through many books, He possessed all the evidence that the prophetic books and the scriptures record.

\section{The Process of the Victor's Reaching Nirvana}

The Victor, Mr. Cho Hee Sung' life was a sacrificial and struggling one against himself. When He was in high school, He helped his friends who did not go to school to go to school by making money at night. In the army, He taught soldiers who did not finish middle school or high school in the day time, taught civilians at night and built 3 schools by himself and made them public schools. Continuing to work hard drove him to the third step of consumption. He was cured in his dream by Mr. Pak Tae-Sun (the spiritual mother) who led Jeondogwan religion in Sosa. The next morning, he found there were two burnt hand prints on his abdomen. His condition was very good. So he went to a hospital and was x-rayed and his consumption was completely cured! That was their first meeting, but Mr. Cho Hee-Sung did not know it. When Mr. Cho Sung first met Mr. Pak Tae-Sun, who already knew that he cured Mr. Cho Hee Sung in his dream. As Mr. Cho Hee-Sung recognized that God accompanied Mr. Pak Tae-Sun, he served Mr. Pak Tae-Sun as God, followed him. He drew his spirit by loving him highly and lived a life in contrast of what he wanted. He prayed without eating or drinking water and sleeping for a month 14 times to kill his ego and draw the spirit of God, among them, one time was on the broken glass and one time, on marbles. When he almost overcame himself (Ego) from the spirit of death, he was taken to the Secret Chamber in Sosa.

The Victress Eve who God accompanied was there. She read all the thoughts of the people. She trained Mr. Cho Hee-Sung to become a Victor. While living a life of objection 100 percent such as not sleeping when He was sleepy, not eating when he was hungry, loving person who hated Him, leaving Himself to God, he killed his Ego (the spirit of death). That day is Oct 15th, 1980. As the Satan in Him died completely, the Trinity God occupied His body and he became a Victor. On that day, He went to a mountain to collect wood, the trees and grasses danced. The trees greeted bending their thick trunks and danced raising one branch up and the other branch down and grasses whose roots were planted in the ground danced up and down. So he realized that he became a Victor. 


\section{The Three Types of the Holy Dew Spirit's Descendant}

There are three types of the Holy Dew, the scriptures and the prophetic books predicted as follows. First, in accordance with Joel 2: 28 30(KJV) in the Bible, "Even on my servants, both men and women, I will pour out my Spirit in those days. I will show wonders in the heavens and on the earth, blood and fire and billows of smoke". Gyeokamyourok predicted the same in its Haeinga. Gyeokamyourok says “火雨 露 甘露海印”,11. It means the Sweet Dew is like fire, rain and dew. In fact, I confirmed through pictures by Film Photographing Field Studies that infinite life span and infinite light falls in various shapes and colors. That Holy Dew Spirit's descending phenomenon cannot be seen in other religions. The men who get out their sin, whose spirit is clean, or the followers of the Victory Altar can see the Holy Dew Spirit fall with their naked eye according to my indirect inquiry investigation. What is the essence of the Holy Dew Spirit?

Examining Psalm 133:3 and Isaiah 26:19, one can see if the Holy Dew Spirit falls, Jehovah in the beginning overcomes the authority of death, becomes the Savior, and saves all humanity from death. That is, I think that the descendant of the Holy Dew Spirit is not the work of humans but the advent of Jehovah in order to destroy the spirit of death. You can see details about the essence of the Holy Spirit in the scriptures to my theses and 『The Hidden Secret of the Bible』Kim Young-Suk on the Amazon.com. According to an American appraisal center, the phenomenon of the Holy Spirit's descendant was revealed by camera. Also it was neither faked at all by something nor added, but it is something real, is like other existence, the descendant of a spiritual object.

\section{The New Methodologies for Research}

(1) Participant observation.

(2) Photograph film.

(3) Interviewing Testimonies by Fieldwork.

(4) The self-experience and Practice Observational Method.

\section{The Role and Experience of the Holy Spirit}

I tried to research scientifically how the light of life emitted from the Victor influences humanity and all things.

The believers of the Victory Altar say they are removing their sin by receiving the Holy Dew Spirit and having the heart of being reborn as the Holy Spirit. Let me introduce their experiences and the process of the changes of their bodies and minds. The Holy Dew Spirit removes the factors of death and evil spirits staying in their bodies, it is a legendary elixir in the Samsin (the Trinity) mountain that Chinese Qin Shi Huang. ${ }^{12}$

\section{Mandala Flower Rain in the Buddhist Scriptures}

The basic aim of Buddhist scriptures is reaching nirvana by receiving the Sweet Dew, according to Bomun part of the Lotus Sutra because the Sweet Dew removes humans' agony, birth, and death. The Buddhist Scriptures express the Sweet Dew (甘露) as the light of the great nirvana that the Reincarnated Maitreya Buddha pours out, the whole of Buddhist scriptures such as, the Great Nirvana Sutra, the Avatamska Sutra, and the Dharma Sutra say the Sweet Dew is the symbol of the Reincarnated Maitreya Buddha. According to volume

\footnotetext{
${ }^{11}$ Refer to Han Gang-Hyen, The Theme was: "The Hidden Manna and the Philosophy of Eternal Life" (Based on the Perspective of Prophecies in Sacred Books) in the 2011 International Conference" by CESNUR.

12 Ibid, refer to Journal Vol 3. Oct. 2015, the purpose of establishing of IANC pp96.
} 
26 of the Avatamska, the Reincarnated Maitreya Buddha can fill the universe with His other selves, in an instance, pour down the Sweet Dew, and remove the agonies of people (分身編十方 甘露雨滅煩惱).

\section{The Phenomena of Amazing Experiences \& Changed Neohumans’ Body (神體)}

The mysterious taste of the Sweet Dew and its real experiences.

When people experience the Sweet Dew, they have the smell of paper burning and the smell of burning decayed blood. That is, that is the smell of burning sin.

- Their whole body becomes hot like a burning ball.

- They feel that cool life water flows from their mouth to their abdomen.

- They smell the strong scent of lilies.

- Their spirit becomes clear and their body becomes light.

- The Sweet Dew is taken by cameras variously as the forms of light.

- Their spirit is changed clean and peaceful.

- Their dirty blood discharges through their urine and feces.

- Terminally ill patients are cured in a moment.

- They feel the phenomenon that their body becomes young (更少年) such as menstrual cycle period starting again, and gray hair becoming black.

\section{The Holy Dew Spirit Is the Immortal Manna.}

After Moses, dew did not fall. Well after that, Isaiah prophet predicted as follows, "Your dew is like the dew of the morning; the earth will cast out death" in Isaiah 26:19. Isaiah foretold if the Savior pours down the dew, death would disappear. Also John 6:27, "Do not work for food that spoils, but for food that endures to eternal life". Furthermore Corinthians 15:54, "When the perishable has been clothed with the imperishable, and the mortal with immortality, then the saying that is written will come true: "Death has been swallowed up in victory”. Tell if the Victor in Revelation 2:17 pours down the Holy Dew Spirit, people eat it and are changed to be imperishable. Being imperishable, they will not die and the Spirit of Death will disappear. So the prediction, "the life-span of humanity is like that of trees' and will be accomplished in coming soon era".

\section{The Theory of Biblical Salvation and the Principle of Scientific Immortality}

The Victor, Mr. Cho Hee Sung said that Catholic, Christianity, new Christianity, Buddhism, and Confucianism did not know that the work of the Holy Spirit and the essence of the Victor, so their salvation theory and Savior's theory are wrong. The Victor and the followers of the Victory Altar present a New Salvation Theory, a new Savior's theory, and a New Heaven Theory.

The detail was already published in this book. Please refer to it. Due to the development of science and medicine, it is revealed one by one that the immortal science of the Victor in the Victory Altar is very biblical, scientific, and medical.

Mr. Cho Hee Sung, the Victor in the Victory Altar explains religion scientifically. Also he says about the theory of salvation and immortality and the qualification of the Savior definitely on May 24th, 2001:

( "This man" refers to Mr. Cho Hee Sung the Savior of the Victory Altar)

You receive life at the moment you meet the Victor.

Only humanity does not gain vigor. This grass and trees receive life from the Savior. All things in the world receive 
life. After you are completely accomplished, you will realize this fact. Therefore, if you are not lucky people, you cannot receive this luck. As This man came to make humanity God and has a duty to create humans God, if He says, "you became God", you will became a God. If there is a person who doubts the words of the Savior, they are fools.

To distinguish the true Savior from the false Savior, the man who speaks of the theory of biblical salvation is the true Savior. Also the man who knows about spirit and God definitely is a Savior. The man who does not know about spirit, God, Satan, and sin cannot become a Savior. If a man does not know about sin, they cannot become Saviors. Also if a religious group does not know about sin, it cannot become a religion. The group where sinners gather is the group of Satan. Also if a religious group does not know the whereabouts of $\sin$, it cannot be a religion. Additionally if one does not know where heaven is built, they cannot be a Savior. If one does not know what heaven is, what hell is, the whereabouts of heaven and hell definitely, they are false Saviors. In addition, the Savior is the man who emits the Holy Dew Spirit according to Hosea 14:5. "I will be like the dew to Israel; he will blossom like a lily". In the word, "I will be like the dew to Israel" Israel is Hebrew, I indicates a Victor, God because he told that word. So, "Israel" in "I will be like the dew to Israel" means a Victor. So the word, "God will be like the dew to Israel" means "God becomes like the dew to the Victor and God falls". The Victor that pours the dew blossoms like a lily.

The Lord is a lily in a mountain valley, the bright morning star, he is the outstanding Lord over all humanity.

As the lyric of the hymn says: "The Lord is a lily in a mountain valley", it means the Savior is a lily. In addition, it says that the Savior is the bright morning star. That is, the Savior is the bright morning star. As the bright morning star is a bright star, the man who has a name of “the bright morning star” is the Savior. So This man's name is bright (熙) star (星). That is, This man has the name of the bright morning star. That is, his name is that of the Savior. "The outstanding Lord over all humanity". As the Savior is the outstanding Lord over all humanity, He cannot be a stupid fellow. Also, the Savior is the man who emits the Holy Dew Spirit. If he cannot pour the Holy Dew Spirit, He is false. According to Genesis 49, Jacob predicted about his 12 sons' future. Genesis 49:16 writes about Dan's future.

"Dan will provide justice for his people. Dan will be a serpent by the roadside, a viper along the path, which bites the horse's heels so that its rider tumbles backward". "I look for your deliverance, O LORD". Jacob gave the right of judgment to Dan, the fifth son, among his 12 sons. The right of judgment belongs to God. It means that Jacob gave the right of judgment, God's exclusive property, to Dan, which means that the spirit of Jacob's God went to Dan. If a religious group does not know this fact, it is not a religion. The spirit of God moved to Abraham, the spirit of Abraham's God moved to Isaac, the spirit of Isaac's God moved to Jacob. The spirit of Jacob's God moved to Dan, the spirit of Dan's God to the Spiritual Mother. The spirit of God in the Spiritual Mother came to This man, the last consummator. Therefore, as This man is the final consummator, He was supposed to emit the dew, whenever He leads a worship service, the dew falls. However, because the dew is the spirit of God, it is not seen to the eye of people. So the Bible records about the theory of salvation as follows. One can be saved by eating the fruit of life according to Genesis 3:22. One can be saved by being reborn as the Holy Spirit in accordance with John 3:5. The word, "One can be saved by being reborn as the Holy Spirit" does not mean that one is saved by receiving the Holy Spirit. However, today Christianity says that people are saved by receiving the Holy Spirit. The Bible surely records, "one is saved by being reborn as the Holy Spirit". That is, the word, "one is saved by being reborn as the Holy Spirit" means as the Holy Spirit is the spirit of God, "one is saved by being reborn as God", it means one is saved only when they become God. It means that humanity cannot be saved. However, there is a person who said that if one believes him, they are saved. This is the non-biblical word.

Humans have no relationship with salvation according to John 3:5 in the Bible. That is: the word, "one is saved by being reborn as the Holy Spirit' means 'one is saved by being reborn as God". That means humanity was God before. The word, "one is saved by being reborn as God" involves "humans were Gods before" in the word. Therefore, as Adam and Eve are the ancestors of humanity, there is evidence in the Bible that they were Gods. The Bible records that Adam and Eve wore the figure of God. Humans cannot wear the figure of God. Only God can wear the figure of God. As they were Gods, they wore the image of God. The word supporting Adam and Eve were Gods is that Adam and Eve lived in the Garden of Eden. The Garden of Eden is heaven. That Adam and Eve lived in heaven is evidence that they were Gods. A hymn states, "Where the Lord resides is heaven". Where humanity stays is not heaven. That is, the condition of fulfilling heaven is only if God resides there, if God does not exist, heaven cannot exist. There are several kinds of God. Other religions do not know that fact. They think God is the same.

However, the steps of qualification to be a God are different.

There is God that lost to Satan and God that overcame Satan. "To the Victor that overcame Satan, God is like the dew" means the God has overcome Satan emits the Holy Dew Spirit, the spirit of God. Before overcoming Satan, God 
cannot emit the Holy Dew Spirit. As the weapon that can defeat Satan is the Holy Dew Spirit, the God that overcomes Satan not only can emit the Holy Dew Spirit but also can build heaven and can live in heaven. If God loses to Satan, he can neither construct heaven nor live in heaven. Every God cannot go to heaven. When God overcomes Satan, he can live in heaven forever because as Satan is the Spirit of Death. If God loses to Satan, the God cannot live forever. So Adam and Eve were Gods, but they lost to Satan and occupied by it, due to eating the Forbidden Fruit, Satan, their controlling spirit, the spirit of God, lost to Satan because the spirit of their God was weak. As they were weaker than Satan, Satan caught them, put into the prison of Satan, and it became their controlling spirit. At the moment Satan became their controlling spirit, Adam and Eve became humans. Today's religion does not know this fact. Consciousness of "I" is Satan, consciousness of "I" is the Forbidden Fruit, and consciousness of "I" is the sin of sins. So the Bible records that consciousness of "I" is Satan. "You act in God". Why does the Bible state this phase? It indicates the opposite meaning that you are acting in Satan. "Acting in God" means "be reborn as the Holy Spirit and consciousness of 'I' becomes God". It means if one becomes a God, they can act in God. Today's religions does not know that fact. If religious groups do not know this fact, they are not religions.

Additionally the Bible says, "Throw 'I' away all the time".

If "I" am saved, why does the Bible record, "throw 'I' away?" As "I" am Satan that is not saved and "I" is the Forbidden Fruit, which is the word of the Bible. According to the Bible, the word of the Bible is a spiritual word. As the forbidden fruit is a spiritual word, it is a spiritual fruit. Because of eating the forbidden fruit and dying, the Forbidden Fruit is killing spirit. The Forbidden Fruit is Satan. Religions do not know that consciousness of "I" is Satan and the Forbidden Fruit. If religious groups do not know about the Forbidden Fruit, they are not religions. The religious groups that do not know the basis of sin and the identity of sin are not religions. The word, "Acting in God" is "being reborn as the Holy Spirit". Also, reading the Bible in detail, there is a word, "if one dies, they perishes"

According to Job 14: 14,

"If one dies, as their energy is cut off, where are they?" It means if one dies, their spirit and all the other things do not exist. Therefore, as consciousness of "I" is Satan and the Spirit of Death, which is a tomb, the spirit of conscience, the spirit of God, in a tomb is caught in a tomb. So people have conscience, but they cannot live continually as conscience dictates. That's because Satan has become the controlling spirit of humanity, conscience (the spirit of God) cannot act.

Therefore, there is a hymn, "the Lord that saved the sinners have been caught for 6000 years". Let's sing together.

The Lord that saved the sinners that have been caught for 6000 years, the gratitude for insisting for me flows from the bottom of my heart.

The face of God that I intensely have missed, I see here, it makes my spirit weep.

The Lord that saved the sinners has been caught for 6000 years is the Savior. Every human cannot be the Lord. According to Mark 12:29, "the Lord our God, the Lord is one".

Only God is the Lord. Normal God cannot be called the Lord. The Victorious God, the God that defeated Satan, and the immortal God is the Lord. The normal God cannot become the Lord. Only the powerful God that can save sinners is the Lord. The man that does not have such power is not God.

The Bible also says about the theory of salvation, "one is saved by eating the fruit of life", "one is saved by being reborn as the Holy Spirit", and "being revived and acting in God". In addition the Bible records, "one achieves salvation due to faith". The Bible says that one is saved due to faith, but people do not know what faith is. If religious groups do not know what faith is, they are neither religions nor religious cult. They are the religion of Satan.

That is, according to Nuke 18:8, until the end of times. It means that there is no faith until the end of the times.

Therefore, as until the end of times, there is not faith, one cannot see about faith. If religious groups do not know what faith is, they are not religions. According to Ephesians 2:8, faith is the gift of God. In the meaning of the word, "gift", the identity of faith is expressed. That is, faith should be virtue or benefit to its receiver. As present should be virtue or benefit, faith is written as the gift of God. So the normal God cannot give it, but the Victorious God can give the present, faith, the faith is immortal spirit. The spirit that gives immortality! The spirit of eternal life is the spirit that defeats Satan and kills Satan, which is faith. The Immortal Spirit is the present of God. Only if one overcomes and kills the Satan of consciousness of "I" in humanity and the spirit of God becomes consciousness of "I", they will become God and live forever. If one becomes God and is occupied by Satan again, they fall into death again. Therefore, only the spirit that defeats Satan can become faith. The spirit that can overcome Satan is the Holy Dew Spirit, which is the fruit of life. The fruit of life is the spirit that gives immortality; it is the spirit that defeats Satan. So This man says that there was no religion. However, the Savior not only can see the theory of salvation but also should have power, so He has a qualification to be 
the Savior. So This man showed His power. This man said, "I will destroy communism". People think that communism collapsed by itself. However, as the believer of the Victory Altar heard that This man said, "I will destroy communism" and guessed that This man removed communism. But they were not convinced that He destroyed communism. When This man led by Gorbachev and used him to remove communism, people thought that Gorbachev destroyed communism and three communists imprisoned him to kill him. Although they tried to kill Gorbachev with a pistol, This man appeared as His other self and said, "if you kill Gorbachev, you will die, too", then they were very scared and could not pull that trigger. This man said, "If you do not flee, you will die". Then they ran away.

One was caught in the airport; another was caught in the station, and the third committed suicide. On the day when Gorbachev was free, a double rainbow raised over the Victory Altar. It was taken by a camera; the picture says it was taken August 23rd, 1991. It was the day when Gorbachev was set free. This man said to you just the day before on the rostrum, "Gorbachev will be free soon". And he was released from house arrest. That is evidence that Savior removed communists. So you believed the fact by then. Additionally, This man said, "typhoons cannot blow to South Korea". He said, "I will stop typhoons". And This man said that He would stop the rainy seasons in South Korea. For 20 years, typhoons have not come to South Korea. Also rainy seasons have disappeared in South Korea for 20 years.

The rain that falls continually from June 15 th to July 15 th is a Korean rainy season. The rain that falls after July 15 th is fall rain. The rain that falls before June 15th is spring rain. So spring rain and fall rain fell a lot. Furthermore, This man said, "I would prevent wars in the Korean Peninsula". Kim Il Sung struggled to start wars, in the end he did not cause wars and died.

In addition, Kim Jeong Il tried to bring about wars sending spy boats to Gangreung. When North Korean navy permeated to the west sea across the 38th parallel, South Korean navy warships went to stop them. At that time, at the North Korean warship, a North Korean navy sailor tried to raise a gun barrel with all his energy. As the fire fell on the North Korean navy sailor's head and he could not haul around. So the gun barrel dropped while being raised. So the North Korean navies did not fire even one artillery shell, and the warship was sunk. Looking at the scene, Kim Jeong Il was discouraged.

As This man is the true Savior, He moves as His other selves like the Spiritual Mother said that the Savior has the power of other-selves. He said that the third Victor has the power of his other selves. Having a power of one's other selves is that one's body is one, but he can split into billions bodies and fills the whole universe. This man's other selves fill the whole universe. So This man's other selves went into each of the 4 billion communists and killed the spirit of communists, Then the communists that liked communism until yesterday and cheered for communism said they hate communism. So communism countries could not exist. So communism collapsed completely. Now is a communism country on the earth now? China has became a democracy. Kim JeongIl of North Korea's leader visited China and learned market economy system and democracy. So North Korea is realizing democracy. They are building a market economy system.

Therefore, there is no more communist on the earth. That is, the Savior annihilated communists completely. Considering only if This man says something, it is accomplished as He says, He has an amazing power. The Savior does not save people healing with His hands one by one.

Looking at people one time, they are saved. As the moment the Savior looks at people, as He has a power to kill the spirit of Satan, at the moment Satan dies, they become Gods. So the Savior should have such power. If one does not have power, they cannot become Saviors. If people are not qualified as the Savior and insist they are the Saviors, just they kill people. Today's religions kill people. There are not religions which give immortality. If religious groups do not give immortality, they are not religions. Religion is something that realizes the truth. Also religion is something that gives eternal life. If a religious group is not able to save people, it is not religion. Religion is something that believes God in order to resemble God and to become God. That is, to become God, one believes in religion. To become humanity, one does not believe in religion. Because humanity is supposed to die. Consciousness of "I" is the Forbidden Fruit, the original sin, and the ghost of death in the Korean language. Therefore, consciousness of "I" finally eat up life. Then humans die.

So only if one has the power to remove consciousness of "I", they are Saviors. If one does not have the power to remove consciousness of "I", the Spirit of Death, they are false. So if religious groups do not know that consciousness of "I" is $\sin$, they cannot be a religion. According to James 1:15, "after desire has conceived, it gives birth to sin; and sin, when it is full-grown, gives birth to death". It says, "desire itself is sin". However, desire itself does not attempt desire but consciousness of "I" attempts desire. So as desire is sin, consciousness of "I" is also sin. No matter how many good thoughts one thinks of, the thoughts are all sin one will die. Therefore, "I" is the forbidden fruit, "I" is Satan. Therefore, all things that "I" act in "I" is all sins. Although "I" walk, it is sin, though "I" pray, it is sin, though I believe in God, it is sin 
to die. If religious groups do not know this fact, they are not religions. Therefore, if religious groups do not know the identity of sin, they are not religions. The man who tells about the identity of sin and the fruit of life is the Savior. The identity of the fruit of life is the spirit that gives immortality and overcomes Satan. The spirit that overcomes Satan is the Holy Dew Spirit. So if one receives the Holy Dew Spirit, it means to receive the spirit that defeats Satan. So if one receives the spirit overcoming Satan, they become Victors. According to Revelations 2: "To him who overcomes, I will give the right to eat from the tree of life". It means that God gives only the Victor that overcomes "I" the fruit of life and makes him live forever.

This means that only the man who eats the fruit of life is saved, only the man who overcomes "I" is saved. If a religious group does not know this fact, which is not a religion. Therefore, the Bible records in several places, if religious groups do not know the basic theory of religion, they are not a religion. Also, people in the world are quarreling each other that the Sabbath is Sunday or Saturday. From Hebrew 4:11 says, "There are people who will participate on the Sabbath and who will not participate on the Sabbath". That is, if the Sabbath is Saturday or Sunday, nobody can not participate on the Sabbath. Everybody spends Sunday and Saturday.

That word means that Saturday and Sunday is not the Sabbath. There is a word that God worked for 6 days and took a rest on the 7th day. With that one word, "God worked for 6 days and took a rest on the 7th day", today Christianity insists Sunday is the Sabbath, and the Seventh-Day Adventist Church insists Saturday is the Sabbath. That's because they do not know the definition of the Sabbath. The Sabbath is the day when God takes a rest. It is not a day when humanity takes a rest. When does God take a rest? God lost to Satan 6000 years ago. Today's religions do not know this fact. Therefore, if God attacks Satan, kills and removes Satan completely, there will be nothing that God has to work. Therefore, when Satan is annihilated completely by the Victor, the Sabbath day of God will be accomplished. The Sabbath day is not a day. It is an everlasting resting day. According to Genesis, God worked for 6 days and rested on the seventh day, it does not say that God worked on 8th day. It means that after the Sabbath day, God will take a rest continually. Isaiah 34:16, "Look in the scroll of the LORD and read: None of these will be missing, not one will lack her mate". The word means that the word of Jehovah has its mate. So the mate of the word, "God worked for six days and took a rest on the seventh day" is 2Peter 3:8, "With the Lord a day is like a thousand years, and a thousand years are like a day". That is, the word, "God worked for 6 days" indicates 6000 years. Calculating a day as 1000 years, 6 days are 6000 years. And seventh day is 7000 years.

That is, God works for 6000 years, what does he do? God was supposed to raise a worker to recover the Garden of Eden. The worker is the Savior. God was supposed to produce the Savior for 6000 years. The man appearing in 4000 years and insists that he is the Savior is the false Savior. The Savior cannot appear in 4000 years. The Savior was supposed to be raised for 6000 years. God raised the Savior for 6000 years and the Savior was supposed to appear the world in 6000 years wearing a body of a man. So the period that the Savior annihilates Satan set as 1000 years. That is, destroying Satan completely for 7000 years, from the years 7000 , God is supposed to enjoy happiness forever. That is heaven; heaven will be built by the Savior. When the Savior builds heaven, will He build heaven in the whole universe or on the earth? He will construct heaven in the whole universe. He is expected to build heaven in the whole universe. Heaven will be built in the whole universe. From that time, the sun will lose its light. The sunlight will become dark, and electric light will disappear, light lamps will disappear. Though one will try to turn on the light, they will not make the light. However, if the Savior annihilates Satan, the light of Satan will disappear. And the light of glory will start from the face of the Savior. If the light of glory starts to shine, as the light will go curly, the holes of rats will become bright. And the opposite side of Korea, America will be bright, too. Because a curve light goes curly. Therefore, the whole earth will neither have darkness nor shade. Only a straight light has shade. Because shade exists, night exists. As the light does not have shade, it goes curly, the whole universe will not have night all the time but it will be daytime all the time. That is, at that time, night will not exist in that world, so people will not sleep. It will be the world where one does not sleep. How will people solve their fatigue? Fatigue will disappear. Fatigue comes from sin, after sin disappears and consciousness of "I" is removed, people cannot feel tired. As one's body becomes light all the time, their condition is always good, and they are happy and pleasant all the time. At that time they will become God and fly. When one lives in that light, all the people who become God will feel pleasant. One will live in indescribable euphoria and joy. The light of glory from the Savior will be a burning ball to Satan or sinners; it will make them jump highly. The hottest temperature in this world is 2000 degrees. The burning ball is hundreds of millions times hotter than 2000 degrees.

As being reborn as the Holy Spirit means being reborn as God, only if one becomes God, they are saved. Only when God overcomes Satan, the God is saved. Therefore, people can see how to achieve salvation definitely if they come the Victory Altar. Because the Savior is in the Victory Altar. As the true Savior is in the Victory Altar, He teaches the 
salvation in detail. This way is that of the mind. The Bible say, "Have only the heart of God". By conceiving the heart of God, one is saved. The Bible says, "conceiving the heart of God" because only God has the heart of God, how can humans have the heart of God? This phrase means, "become God". If consciousness of "I" becomes God, they can have the heart of God. Also, the word, "act God" means becoming God, the word, "being reborn as the Holy Spirit" means becoming God. Additionally the word, "eat the fruit of life" means becoming God. As the fruit of life itself is the spirit of God, before one becomes the spirit of God that defeats Satan, one cannot eat the fruit of life. The fruit of life is the spirit of God that overcomes Satan. The spirit of God that defeats Satan is not only the fruit of life but also faith. Therefore, the end of times is the end (末) and humanity (世). It means the end of the world of Satan. All humanity is Satan. As their controlling spirit is Satan, their owners are Satan. So humanity is Satan. If a religious group does not know the fact, it cannot be religion. Humans all are Satan. So the word, "to become God" to people, Satan, means that only if one is reborn as the Holy Spirit, they are saved. In order to become God, they should defeat Satan, kill and remove Satan, and then they will become God and be saved.

The Bible writes like that, there was nobody who knew about it and said it in detail. Because the hero of the Bible did not come. The hero of the Bible is the Savior. Normal people cannot become the Savior. Adam and Eve were Gods and they are the Trinity with another God. Christianity says, "the Trinity is God, Jesus, and the Holy Spirit". It means that in old times, there was not the Trinity. In other words, Christianity's insistence means that after Jesus appeared, the Trinity existed, before the advent of Jesus, there was no the Trinity. The Trinity was God, Adam God and Eve God, too. So Adam and Eve wore the figure of God according to the Bible. The Bible wrote like that, today people, Satan, recorded the Bible. As people wrote the Bible, it means that Satan wrote the Bible. In order for Satan to possess the children of humanity and the world of Satan forever, as it is now, the Bible recorded that Adam and Eve were created with soil. However, the word, "Adam and Eve were made by soil" exists only in one place. According to Isaiah 34:16, the word of Jehovah has its mate. That is, the word that has no its mate is not the word of God. Satan wrote like that in order to deceive the children of God. That is, the Bible records that God created humans with soil and he made all things. In fact, humanity and all things were not created. In fact, God was light. Satan split the spirit of God, the spirit of light, with a line of latitude a line of longitude, and locked in everything. So This man explains scientifically that there is the spirit of God in material. This man said that there is a nucleus in all material's element, in a nucleus, there are neutrons. Electronics go around neutrons continually. Each element gathers and forms material. Today's scientist know that electrons go around neutrons by themselves. Going around by themselves is illogical. As there is a power to go around, electrons go around. If there is not a power to go around, how can they go around? The saying that as neuron is the spirit of God, the spirit of God is the spirit of life, due to the life power of neutron, that electrons go around is a reasonable logic. So a logical learning is established. However, the reason that today's the cutting-edge science do not know this fact is because they are also Satan. All these materials themselves are the spirit. That is, This man said that neutrons exist in element of materials, electrons go around outside of neutrons, electrons are the spirit of Satan. So the coexistence of the spirit of Satan and the spirit of God is material. Material in the world itself is spirit. The reason that here flowers are living is because the spirit of God is in them, life exists in them. Life itself is the spirit of God according to John 1:1. It records that God is life. Also it says that God is light. "Life is blood, blood is life according to Leviticus 17:11. Like this, life is blood, blood is life. Therefore, blood in humans is life. Mind is formed by the effect of blood. So mind itself is the source of life according to Proverbs. "The source of life is in the heart". It means that the source of life is mind. Mind is the effect of blood. That is, the word, "blood is life, mind is life" is a right word. Therefore, when people die, their mind dies and their life dies. As the source of life is in heart, when people die, their heart dies. So a dead person does not have their heart. Because heart dies, it does not exist. There is a saying, "heart leaves when they die". As all religions in this world are the religions of Satan, all their words are manipulated. The spirit does not leave. The spirit is in our blood. As heart is spirit, the Bible records like that. That is, the blood is spirit. As blood is spirit, flesh and body are formed with blood. The body of mankind itself is spirit. The word, the body of humans separates from spirit is as Satan is dividing spirit, it says dividing one into two. That is, the body of humans is spirit, the body of humanity itself is God, the body of humans is spirit. So Numbers 16:22 says, "God is that of body". Reading the Bible, it says in detail.

God exists in humans. God is not in the air. God is in humans and nature. God becomes the captive of Satan and is locked in all material and humanity. Things that exist as life are all Gods. Therefore, if God exists in the air; he is locked in the prison of Satan. According to Ephesians 6:12, Satan is in the air. Also according to Matthew 10:18, Jesus said that he saw Satan fall from the sky. As Satan exists in the sky, Satan fell from the sky.

If God exists in the sky, Satan cannot fall from the sky. That is, Satan is in the sky. That is, when Jesus went up out of 
the water in the Jordan River, at that moment heaven was opened, and there was a voice from the sky, "This is my Son, whom I love; with him I am well pleased". in accordance with Matthew 3:16-17. That word means that Jesus is the son of Satan. Although the Bible says that Jesus is the son of Satan, people believe that Jesus is the son of God. As they are the children of Satan, the God of Satan's sons is Satan naturally. So the true Savior was supposed to come and teach the words of the Bible exactly by splitting them. So He was supposed to teach distinguishing Satan and God. By teaching the word of the Bible exactly, people were supposed not to follow the false Savior and not to die. If one follows Satan, they will surely die. The 6000 year history of humans has flowed; there was nobody that said like this. There was nobody who taught the Bible exactly digging through and through.

According to the Old Testament, there is no word that spirit starts. Therefore, when people die, as their life dies, they die. The life of people is blood, blood is the heart, heart is the spirit. Therefore, when people die, their spirit dies. As there is the spirit of God in people, hearts exist in them. And as God exists in one, spirit exists in them. So when Satan kills God, it does not kill people. As the life of humans is God, because Satan kills the life of humanity, the spirit of God, at the moment, humans die. So Job 14:14 of the Bible says if people die, they perish. Does perishing mean that spirit leaves?

No, it doesn't. So one can see the true Savior by listening to His words. The difference between the false Savior and the true Savior is that there is nothing that the true Savior does not know. He knows everything. That is the true Savior. Also there is nothing that the True Savior cannot do. He can do everything. As This man has nothing he cannot do, He is the almighty Savior. If the Savior is not omniscient and omnipotent, he is a false Savior.

Therefore, you can know the true Savior and the false Savior by listening to their words and seeing that power.

In the process of my study, I came to know that the new religious movement occurring in Korea is very unique and cannot be seen in other countries.

Especially, for the first time in human history, Mr. Cho Hee Sung, the Savior in the Victory Altar, the Gold Angel who is foretold as the last angel as well as the Victor in Revelation Book, the Maitreya Buddha in the Buddhist scriptures, wears a body of a man, has decoded the predictions in the Bible, the Buddhist scriptures, and in all the prophetic books in each country. Also Mr. Cho Hee Sung emits the Holy Dew Spirit, the hidden manna, which has been predicted in all the scriptures as the immortal spirit. Additionally he has exercised almighty power such as keeping typhoons coming to South Korea and stopping rainy seasons in South Korea as his other selves, for 36 years. It is necessary for Korean new religion and the world new religion to notice that Mr. Cho Hee Sung is qualified as the Savior as the Victor in predicted in Revelation Book and the Maitreya Buddha in the Nirvana Sutra considering his power and symbols. People from Confucianism, Buddhism, Christianity, and Korean traditional religions have experienced the descendant of the Holy Dew Spirit, the hidden manna, for 36 years and have changed a lot in the Victory Altar in Gyeonggi province in South Korea. That means that the ultimate aim of the world religious movement and humanities' dreams have come true. The sermon of Mr. Cho Hee Sung in the Victory Altar suggests that what is a scientific religion and what is a hyper religious science.

I am sure if we study religion as the scriptures say without adding humans' thoughts or guess, and attempts to find the common key points in all the scripture synthetically like Mr. Cho Hee Sung, the essence of the paradise, the new heaven, the hidden manna (the fruit of life), the secrets of immortality and the role and importance of neohumans will be revealed soon.

\section{Conclusion}

The Korean modern religious status and the geography of the world religions is changing rapidly. The meeting of science and religion is progressing in the world.

In order to be admitted as the Savior by the Bible and all the scriptures, the man should answer to $5 \mathrm{Wh}$ and 1 How Questions on the qualification to be the Savior. The qualifications of the Savior in the scriptures are 
common. The symbol of the Victor in Revelation Book, the Maitreya Buddha in the Nirvana Sutra, and the Savior in several prophetic books such as $\ulcorner$ Gyeokamyourok (格庵遺錄)」, Korean prophetic book with 100 percent accuracy and Sanhaegyeong (山海經), a Chinese book has written the hidden manna (the Holy Dew Spirit, the Sweet Dew). The Bible records the Victor as "the Bright Morning Star". A hymn that a lot of Christians sing says that the Savior is the bright morning star. However, nobody revealed what the name of the Savior is and who the Savior is. As each person insists that they are the son of heaven, knight in the Second Coming, the Maitreya Buddha, and the Victor, they confuse the societies with empty and incomplete teachings. If one is the true Savior, they should reveal all of the hidden secrets in the Bible and all the scriptures. He should know the name on the White Stone in Revelation. Mr. Cho Hee-Sung of the Victory Altar has fulfilled the three necessities. According to Mr. Cho Hee-Sung, he received the 'White Stone' at his age 7, which had a name on it. He said that “The name was Sosa (素沙)". He built the Victory Altar in the Sosa area in 1981. That is, He received the land of the secret code, Sosa (White Stone). His name (熙星) means the Bright Star. Mr. Cho Hee-Sung has poured down the hidden manna (the Holy Dew Spirit) that enables humanity's anguish, sin, and pain to be removed and to make new heaven in their minds and has changed them immortal ones. In addition, many the scholars of Confucianism, monks, Christians, and ministers came to the Victory Altar and witnessed the truth that they experienced the Holy Dew Spirit which really fell down. The recordings said that the seekers of truth from a lot of religions were called to the Victory Altar by the Lord. The recording of people admitted that the true way is realizing the land of happiness in the present, will be a good example to all religions, and will give hope the seekers of truth. ${ }^{13}$

Additionally, according to the study and analysis of the writer, the Seventh Angel that has the power of His other selves and can change his body still pours down the Sweet Dew in the Victory Altar all the time after returning to his original light. Plus, the conviction that the sayings of the Seventh Angel surely will come true makes the followers of the Victory Altar keep going toward the aim of eternal life. Also, the followers of the Victory Altar are convinced that they can accomplish immortality and those who keep "the Law of Liberty" well can feel like their body is in their twenties although they are old. They confirm by a test that their blood becomes clean for their age.

Finally, after studying the paranormal phenomena and 5 covenants of the Victor of the Victory Altar deeply, 5 covenants and the grace of the Holy Dew Spirit that nobody dare says that the word of Mr. Cho Hee Sung, the Victor in the Victory Altar, he is recognizing by them not a man in the world but God himself directly appeared to open a new heaven wearing a body of a man. In fact, all scriptures prophesied if the Holy Dew Spirit falls, the immortal era will come, which is the secret of new heaven hidden in the work of Korean new religious movement. As I said in introduction, due to humanity's desire, anguish, blind faiths, and idolatry, a lot of people killed people and made others as their enemies. I think that the roles of the existing religions are finished. Considering this phenomenon, the word of the Victor in the Victory Altar, "so far there was no true

13 According to Lee Sangho, (李祥吴), 『大巡典經』, (Jeongju: the headquarter of Jeungsan, 1979); Gang SengSan (the Angel of Fire-Luck), the creator of Jeungsan religion, predicted the phenomenon of the era of the Maitreya Buddha through Daesoon scripture (『大巡典經』) as follows. Chapter 3, page 162 of Daesoon scripture 『大巡典經』 which was published by the headquarter of Sengsan religion records that Gang Jeung San told his followers that 耶蘇呚徒 (Christians are waiting for the Second Coming of Jesus (再降臨), Buddhists (佛敎徒) are waiting for the advent of the Maitreya Buddha (彌勒), the followers of Donghak (東學信徒) waiting for the advent of Choi Su Woon (崔水雲 更生). But only a man appears, each of them will insist that he is their teacher and follower him. As well, Chapter 3, page 162 of the same scripture writes, "Gang Jeung San said that no matter how hard you try to find him, you cannot see, when I find, you will see me". 
religion" seems right. In fact, religion is something that enables humanity to live forever according to John 5:39. Before the Holy Dew Spirit (the immortal spirit) comes, physical immortality(salvation) is impossible in accordance with all the scriptures. It is the time when religionists, believers, and religion researchers rethink of the existing definition and role of religion.

\section{References}

Gyoujanggak. (1878). 濟衆甘露 (jaejonggamro). No, 奎19181, 1-150.

Han, G. H. (2002). The study of prophecy of Gyeokamyourok the culture of prophecy of Korea and the Victory Altar (勝利祭壇).

Tokyo: Mejiro University Graduate School (目白大學院).

Han, G. H. (2011). The Hidden Manna and the philosophy of eternal life (Based on the perspective of prophecies in Sacred Books). Proceedings from the International Conference.

Han, G. H. (2011). The study for exodus from birth and death \& The theory of eternal life (On the focus the philosophy of Immortality. Journal of the Korean Academy of New Religion, 24, 67-127.

Han, G. H. (2012). A new view of the afterlife and the New Heaven. CESNUR Morocco.

Ko, S. Y. (2012). The new culture movement of CheunDoKyeou. Journal of the Korean Academy of New Religions, $27,97-25$.

Lee, K. W. (2013). The tentative discussion for establishing a culture in Neohumans' era. Journal of Neohumans Culture, 2, 9-27.

Nam Sa Go. (1550- ). 格菴遺錄 (Gyeokamyourok). Korea National Central Library, No, 1496-4, 24-41. 